\title{
Posouzení napadení objektu plísněmi
}

\section{Assessment of Mold Invasion in Buildings}

\author{
Ilona Kukletová*, Pavel Buchta
}

Výzkumný ústav stavebnich hmot, a.s., Brno

\begin{abstract}
Abstrakt
V současné době se stále častěji setkáváme s problémem plísní, které kolonizují povrchy staveb, a to jak vnitřní, tak vnější. Hlavním důvodem těchto problémů je změna životního stylu a s tím související způsob užívání a vytápění bytových, pracovních a výrobních prostor a narušení životního prostředí. Konkrétní př́íčina pak úzce souvisí se stavebními závadami, nevhodnými projekty, izolačními systémy nebo s nevhodným užíváním prostor. Mikroskopické houby kromě narušování substrátu, na němž rostou, přinášejí i další nežádoucí důsledky. Příspěvek je věnován problematice růstu plísní v interiérech včetně negativních dopadů na člověka, možnost stanovení kontaminace a odhalení příčin. Součástí př́ispěvku jsou ukázky konkrétních případů. Příspěvek byl prezentován na konferenci ExFoS 2019, 24.-25. 1. 2019 v Brně.
\end{abstract}

Klíčová slova: plísně, budovy, příčina, vlhkost, stavební závady, nevhodné užívání.

\section{1. ÚVOD}

Biologickou destrukcí bývají v různé míře zasaženy veškeré části stavebního díla, a to jak u novodobých, tak u historických objektů. Pravá př́čina biodegradace bývá často zaměňována za důsledky působení klimatických degradačních vlivů. Odstranění biotických činitelů tím bývá oddáleno, či vůbec znemožněno. Mikrobní napadení staveb však nese s sebou i riziko vzniku zdravotních problémů, což je v současné době zatím opomíjená problematika [1]. Stavby negativně ovlivňují tyto hlavní skupiny organismů: plísně a bakterie, dřevokazné houby, řasy a lišejníky, hmyz. Zejména plísně pak mají velmi negativní vliv na zdraví člověka. Nejčastějšími důvody mikrobiologického poškození staveb jsou nevhodné projekty a konstrukční chyby, nevhodná nebo chybějící povrchová úprava, opomenutí speciálních podmínek prostředí, izolační systémy staveb, ale také havárie a chyby při užívání staveb [2].

\begin{abstract}
:
Nowadays we more often meet the problem of molds that colonize the surfaces and structures of buildings, both internal and external. The main reason for these problems is the change in lifestyle and the related ways of use and heating of residential, work and production areas and environmental disruption. The specific cause is closely related to building defects, inappropriate projects, insulation systems, or inappropriate use of building space. Microscopic fungi, in addition to disturbing the substrate on which they grow, also bring other undesirable consequences. The article discusses possibilities of mold growth in the interiors including negative impacts on humans, contamination and detection of causes. Part of the paper is an example of specific cases. The paper was presented at the ExFoS Conference 2019, 24-25 January 2019 in Brno.
\end{abstract}

Keywords: molds, buildings, cause, humidity, construction defects, inappropriate using.

Vláknité plísně jako nejvýznamnější eukaryotické1) mikroorganismy jsou důležitým objektem environmentální mikrobiologie. Do bytů i jiných vnitřních prostor jsou nejčastěji přinášeny venkovním vzduchem. Při průzkumu, uskutečněném v Praze již v 90. letech 20. století, bylo zjištěno, že k nejhojnějším druhům, které se šiří vzduchem, patří zástupci rodů Cladosporium, Alternaria, Aureobasidium, Botrytis, Epicoccum a Penicillium [3].

Plísně se rozmnožují rozrůstáním mycelia (podhoubí) a sporami. Spory jsou rozmnožovacími útvary plísní. Po dopadu spory na vlhké místo $\mathrm{s}$ živinami začne spora plísně kličit, poté roste a vytváří reprodukční orgány. Z nich jsou do okolního prostředí

1) Eukaryota (též Eukarya či česky jaderní) je velká skupina (doména) jednobuněčných a mnohobuněčných organismů, jako jsou např́klad živočichové, rostliny, houby nebo prvoci. Eukaryotická buňka na rozdíl od prokaryotní obsahuje pravé buněčné jádro a množství dalších organel oddělených membránou od okolí. (https://cs.wikipedia.org/wiki/Eukaryota). 
uvolňovány zralé spory. Ty jsou velmi malé a lehké, a tak jsou unášeny vzduchem na velké vzdálenosti [2]. Pokud mají vhodné podmínky pro sporulaci (proces formování spor), rostou na stěnách nebo i jiných materiálech ve vnitřním i vnějším prostředí budov.

Pro růst plísní na zdech a různých substrátech $\mathrm{v}$ domech a bytech je limitující vlhkost, která nemusí být nijak vysoká; důležitá je biologická dostupnost vody. Podle druhového zastoupení pak můžeme usuzovat na stupeň vlhkosti substrátu a naopak. Na místech, kde je vlhkost zřejmá na první pohled, nejčastěji nalezneme hydrofilní rody jako je Alternaria, Epicoccum, Fusarium, Phoma, Stachybotrys, Trichoderma, Ulocladium. Na vlhkých místech se často vyskytují rody Cladosporium, Mucor, Rhizopus. Rody Aspergillus a Penicillium jsou xerofilní (suchomilné) a vyskytují se spíše na sušších místech. [4].

Obecně platí, že mikroskopické houby ve vnitřních prostorech kromě narušování substrátu, na němž rostou, přinášejí i další nežádoucí důsledky. Mohou velmi negativně ovlivnit zdraví člověka, nebot' se významně podílejí na celé řadě alergických a mykotických onemocnění. Vytvářejí ve svých hyfách (vláknech) a sporách specifické proteiny, glykoproteiny, polysacharidy a mnoho dalších látek, které mohou u citlivých jedinců po vdechnutí spor způsobovat alergické reakce. Právě nejčastější houby v ovzduší a na stěnách, jako rody Cladosporium a Alternaria, jsou také nejvýznamnějšími původci alergií. Dalším produktem těchto mikroskopických hub mohou být mykotoxiny, které se $\mathrm{v}$ menši míře dostávají do ovzduší a mohou mít kancerogenní a toxické účinky [2]. Většina těchto hub může mít i patogenní účinky pro imunitně oslabené jedince. Některé druhy také do prostředí uvolňují těkavé metabolity, např. sekundární alkohol 1-octen-3-ol (charakteristický houbovým pachem), různé aldehydy, ketony, mono- i seskviterpeny (terpeny, skládající se ze tř́ isoprenových jednotek), často nepř́jemně zapáchající. Tyto látky často vyvolávají bolesti hlavy a pálení očí. Mikroskopické houby tak mohou být jedním z faktorů přispívajících ke vzniku syndromu nemocných budov (sick-building syndrome) [3, 5].

Limit pro výskyt plísní v bytech není uveden v současné době v žádném legislativním podkladu v ČR, v rámci Evropské unie ani jinde ve světě. Existuje pouze limit pro výskyt plísní stanovený vyhláškou č. 6/2003 MZČR „O fyzikálních, chemických a biologických ukazatelích pro vnitřní prostředí pobytových místnostî“ “ [8]. Přestože byty nejsou dle výkladu zákona pobytovými místnostmi, hodnotí se v současné době podle této legislativy [6]. Hygienický limit je pro tyto místnosti 500 kolonií tvořících jednotek $(\mathrm{KTJ}) / \mathrm{m}^{3}$. Na stěnách a površích místností nesmí být viditelný nárůst plísní, ve sporných př́ípadech se považuje za prokázaný nález, který je potvrzen odběrem a kultivací v souladu s ČSN ISO 7954 [9].

Pro posouzení napadení objektu plísněmi a nalezení příčiny napadení je nutno provést celou řadu měření a stanovení - jak na místě, tak v laboratoři. Pro komplexní obraz problému je ideální spolupráce odborníků z oblasti stavebnictví a mikrobiologie.

\section{POSOUZENÍ NAPADENÍ OBJEKTU PLÍSNĚMI A JEHO PŘÍČINY}

\subsection{Používané nástroje a měření}

Cílem posouzení je rychlá diagnostika míry poškození vnitřních i vnějších povrchových ploch budov, odhalení tepelných mostů, míst s pravděpodobným kondenzačním potenciálem a biotickým napadením, které slouží pro podporu rozhodování o nutnosti sanačního nebo prevenčního zásahu proti mikroorganismům, vyskytujícím se na stavebních konstrukcích.

Využívají se především tyto nástroje:

- Rekognoskace místa měření - zákres do připraveného plánku s orientací ke světovým stranám včetně míst odběrů a měření, fotodokumentace objektu, vyhledání problematických skutečností vně objektu - zdroje znečištění ovzduší, komíny, výdechy vzduchotechniky, centrální klimatizace, termoizolace obvodového pláště, dále vnitřní prostory - popis a zákres vybavení vnitřních prostor s možným vlivem na teplotně klimatické poměry ve vnitřním prostoru, zdroj a způsob vytápění, pokud je do zájmové oblasti situován, odtahy, průduchy, popis těsnících nebo netěsnících oken, dveří.

- Termografické měření na místě - aplikovaná termografie se využívá k detekci a lokalizací tepelných mostů, lokalizací netěsností vzduchotěsné obálky budovy, průběhů dějů souvisejících s teplotou (ochlazování konstrukce, např. při dešti nebo při náběhu chladicího systému; ohřívání konstrukce, např. při požáru nebo při náběhu topného systému), vyhledávání a lokalizaci míst s potenciálem rosného bodu, vyhledávání netěsností v rozvodech tam, kde je rozváděno médium o jiné teplotě než teplota prostředí, hledání lokálních změn teplot u vybavení stavby.

- Měření mikroklimatických podmínek na místě - tlak, teplota, ale především vlhkost vzduchu a koncentrace $\mathrm{CO}_{2}$.

- Měření vlhkosti zdiva - na vytipovaných problematických místech.

- Odběr biologického materiálu z povrchu stěny - průkaz růstu, rodová identifikace, kvantifikace napadení; odběr je prováděn stěrem nebo otiskem a následně kultivován a vyhodnocen v laboratoři.

- Odběr vzduchu v prostoru za účelem kvantifikace spor v ovzduší - odběr je prováděn pomocí aeroskopu a následně kultivován a vyhodnocen v laboratoři.

\subsection{Konkrétní príípady posouzení objektu}

\subsubsection{Př́ípad č. 1 - novostavba bytového domu}

Jedná se o posouzení bytové podkrovní jednotky v novostavbě bytového domu $-2+\mathrm{kk}$ spojeno s podkrovní místností. Během posledních dvou měsíců přibylo činností zvyšujících vlhkost v bytě (praní, sušení prádla, vaření), problémy byly ale pozorovány i před touto dobou. $\mathrm{V}$ podkrovní místnosti černozelená plíseň $\mathrm{v}$ celém pásu za knihovnou - likvidace prostředkem proti plísním měsíc před datem odběru, $\mathrm{v}$ ostatních místnostech v rozích drobná ložiska, okolo balkonových dveří pás šedozelené plísně.

Mikroklimatické podmínky si majitel kontroluje sám, relativní vlhkost ovzduší reguluje do $55 \%$. Zvýšená vlhkost zdi byla naměřena pouze $\mathrm{v}$ rozích zkoseného stropu až $5,1 \%$.

Na obr. 1 je prezentován dům případu č. 1 z přední a štítové strany. Na obr. 2 a 4 jsou fotografie kritických míst a jejich termosnímky nejtmavší barva zobrazuje nejchladnější oblast stěny. Na obr. 3 a 5 je fotografie Petriho misky s kultivací stěru z kritických míst.

Závěr: Kombinací metod se studiem projektové dokumentace bylo zjištěno, že zdrojem vlhkosti je nedostatečně zateplená štítová zed', nevhodně provedené tepelně izolační přechody šikmých 

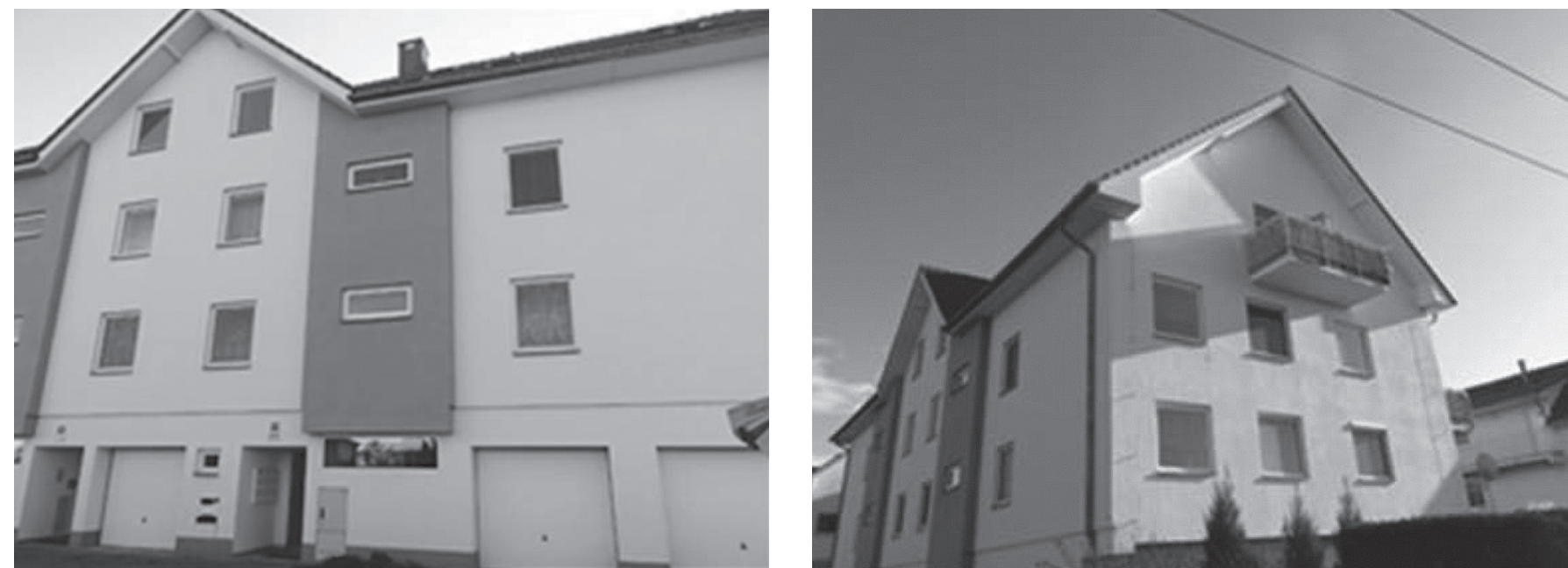

Obr. 1 Celkový pohled na bytový dům - přední a štítová strana.

Fig. 1 General view at the apartment house - the front and the gable side.
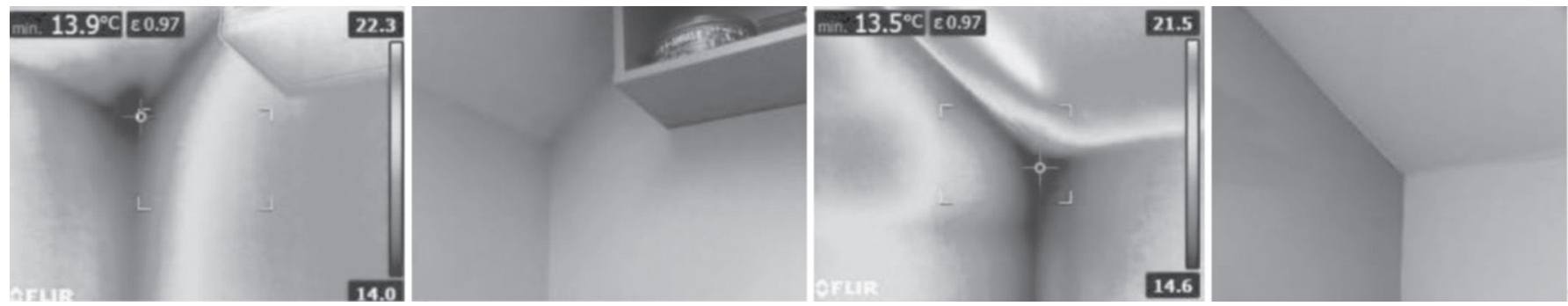

Obr. 2 Rohy zkoseného stropu spodních mistností-termosnímek a fotografie.

Fig. 2 Corners of the chamfered ceiling of the lower rooms - thermo and photo.
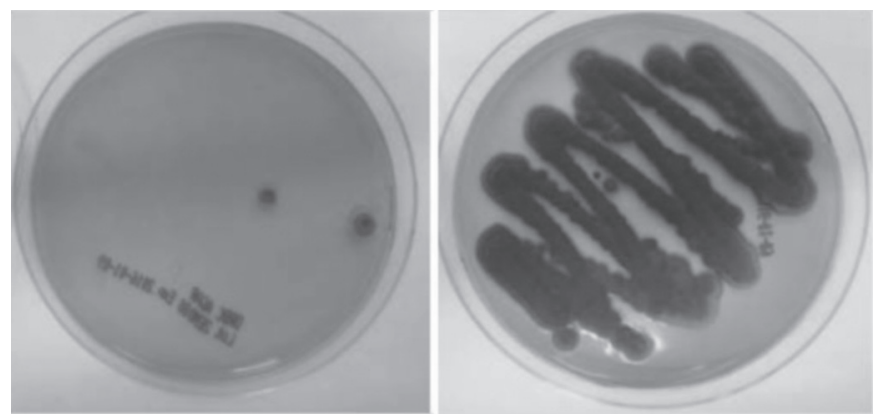

Obr. 3 Rohy zkoseného stropu spodnich místností - kultivace stěru.

Fig. 3 Corners of the chamfered ceiling of the lower rooms-cultivation of swab.
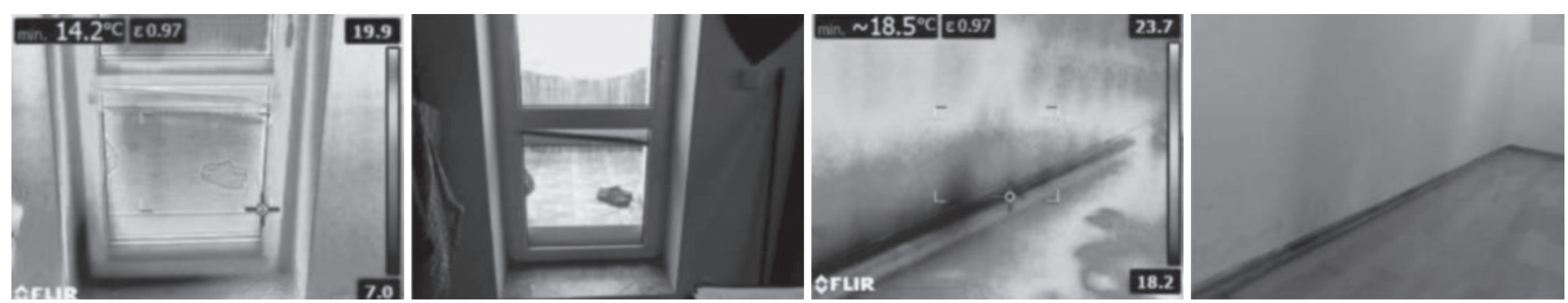

Obr. 4 Balkonové dveře a stěna za knihovnou v podkroví-termosnimek a fotografie.

Fig. 4 Balcony door and wall behind the bookcase in the attic-thermo and photo. 

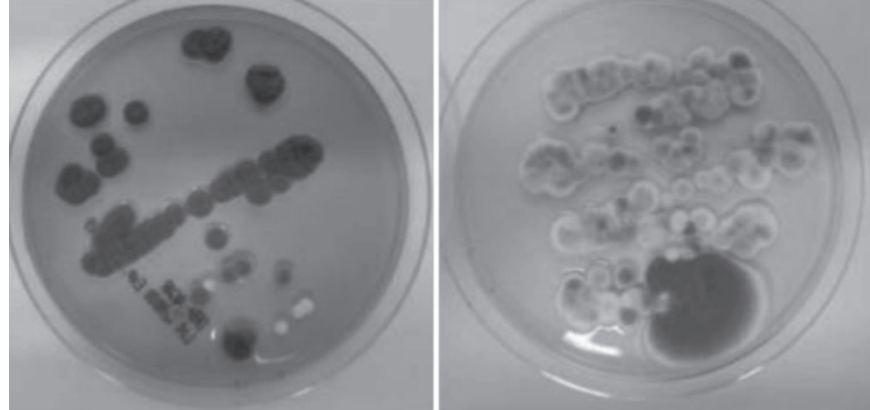

Obr. 5 Balkonové dveře a stěna za knihovnou v podkroví-kultivace stěru.

Fig. 5 Balcony door and wall behind the bookcase in the attic-cultivation of swab.

podkrovních ploch a svislých zdí, tepelné mosty vysunutého schodiště bezprostředně sousedícího s místnostmi a nedostatečně izolovaná připojovací spára balkonových dveří.

\subsubsection{Př́pad č. 2-bytový di̊m po podkrovní vestavbě}

Byt ve 3. nadzemním podlaží nájemního domu. Dům je zateplený a po obnově fasády - současně dodělána půdní vestavba nad 3. nadzemním podlažím. Byt opakovaně kolonizován plísněmi $\mathrm{v}$ širokých pruzích $\mathrm{v}$ horní části stěn. Nájemce stav připisuje nevhodnému užívání bytu.
Vlhkost vzduchu v bytové jednotce 65,7\% \%. Měrení vlhkosti zdiva potvrzuje hromadění vlhkosti v obvodovém zdivu - ve výšce $10 \mathrm{~cm}$ pod stropem bylo naměřeno až 5,8\%.

Na obr. 6 je prezentován dům př́ípadu č. 2 pohledem na jihovýchodní a severovýchodní stěnu. Na obr. 7 jsou fotografie kritických míst a jejich termosnímky - nejtmavší barva zobrazuje nejchladnější oblast stěny. Na obr. 8 je fotografie Petriho misky s kultivací stěru z kritických míst. Na obr. 9 je fotografie Petriho misky s kultivací po odběru vzduchu aeroskopem. Na obr. 10 je schematicky znázorněn problémový prostor.

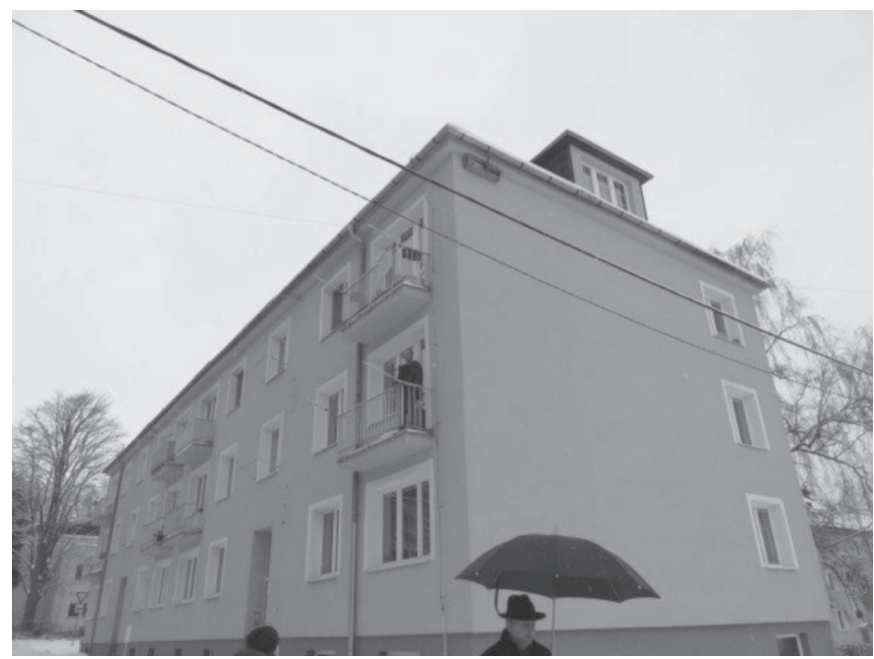

Obr. 6 Düm-pohled na jihovýchodni a severovýchodní stěny.

Fig. 6 House-view at the south-east and north-east walls.

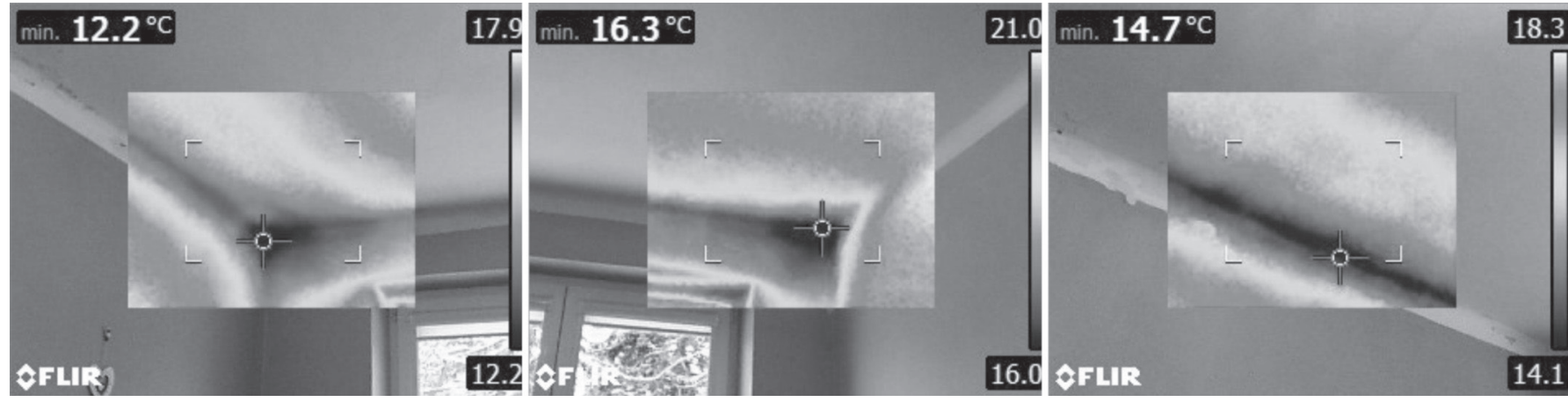

Obr. 7 Obývací pokoj-strop-termosnimek a fotografie.

Fig. 7 Living room - ceiling - thermo and photo. 


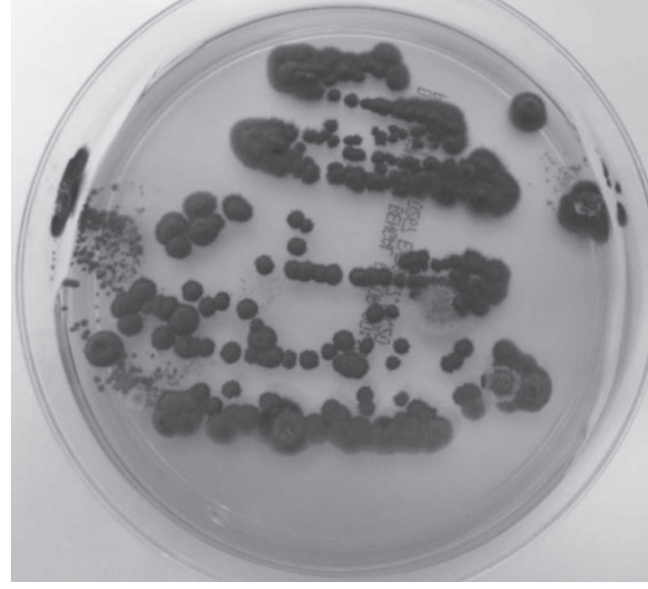

Obr. 8 Kultivace stěru-pás pod stropem obývacího pokoje. Fig. 8 Cultivation of swab-zone under the ceiling of the living room.

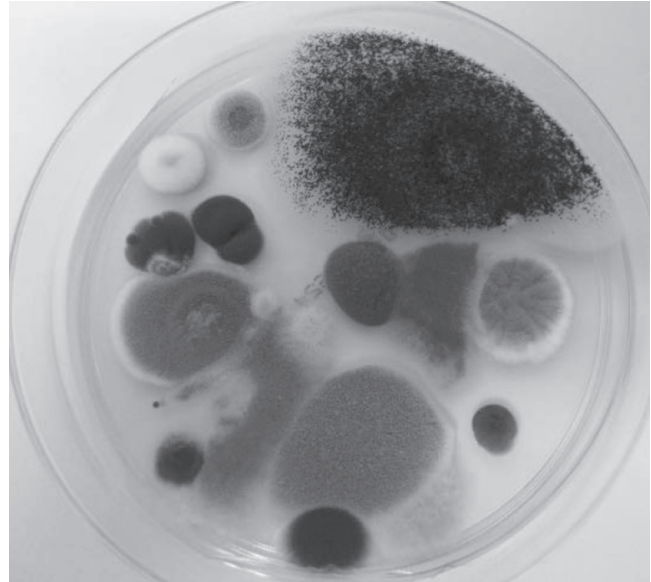

Obr. 9 Kultivace po odběru vzduchu aeroskopem - 104 KTJ (kolonii tvoŕicich jednotek) $/ \mathrm{m}^{3}$.

Fig. 9 Cultivation after air sampling by aeroscope - $104 \mathrm{CFU}$ (colony forming unit) $/ \mathrm{m}^{3}$.

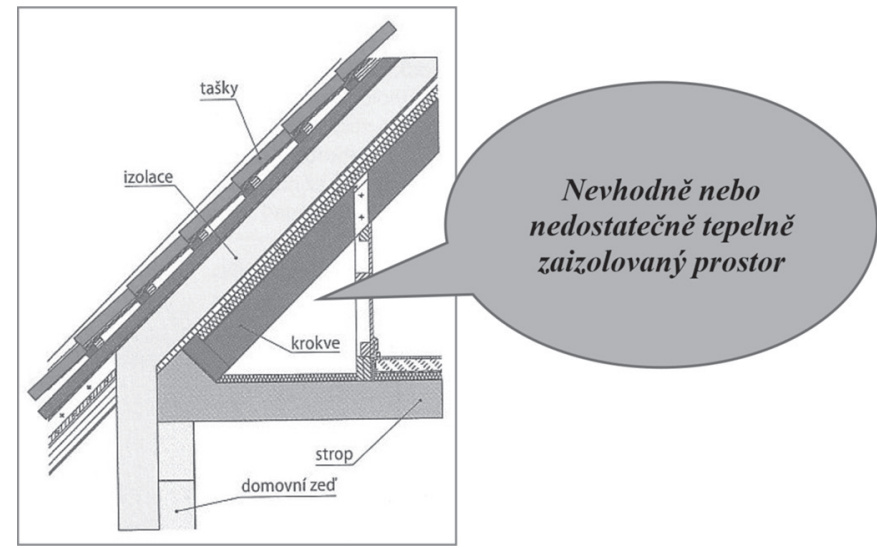

Obr. 10 Meziprostor s kritickou kondenzaci vlhkosti.

Fig. 10 Intermediate space with critical condensation of moisture.

Závěr: Zdrojem vlhkosti je nevhodné provedení tepelné izolace podkrovní vestavby ve střešních šikminách, kde dochází ke kondenzaci vzdušné vlhkosti z indooru (vnitřního prostoru) do obvodových zdí. Došlo tak ke vzniku tepelných mostů s projevem masivních nárůstů plísní, včetně alergizujících a patogenních druhů jako je Aspergilus niger.

\subsubsection{Př́pad č. 3 - novostavba rodinného domu}

Novostavba rodinného domu vybavená vzduchotechnikou včetně rekuperace a podlahového topení je druhým rokem obydlena. Před čtyřmi měsíci došlo $\mathrm{k}$ dobudování venkovní terasy, následně počátkem topného období je v rohu obytné kuchyně opakovaně zaznamenán zápach plísně, který se zesiluje se spuštěním

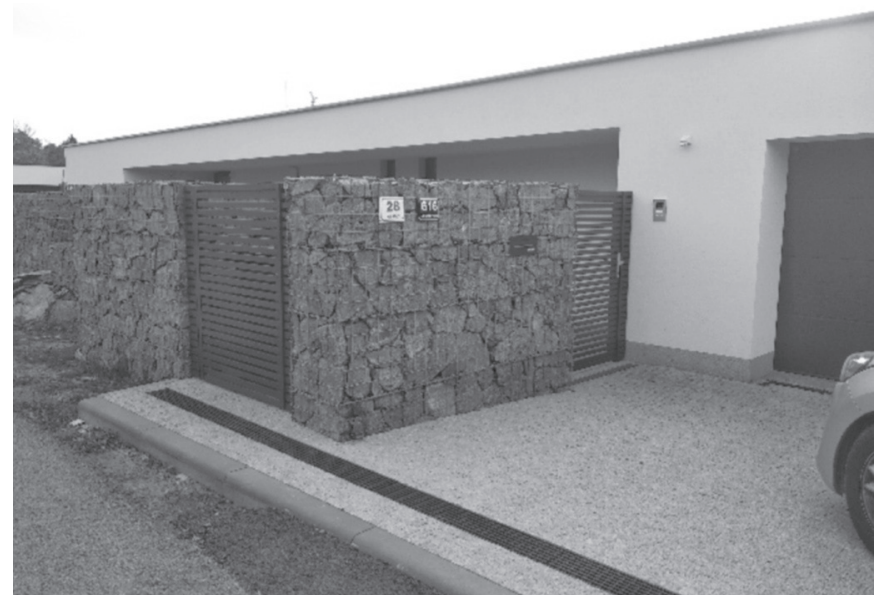

Obr. 11 Dìm - pohled na severni stranu objektu.

Fig. 11 House - view at the north side of the building. 


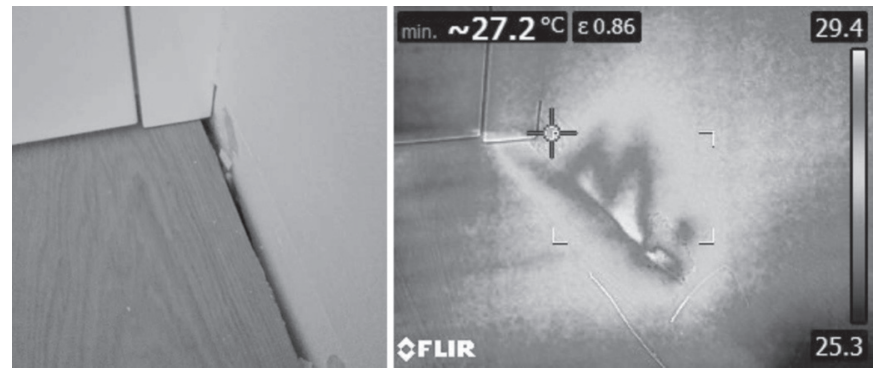

Obr. 12 Problematický roh po odstranění podlahové lišty-termosnimek a fotografie.

Fig. 12 Problematic corner after floor strip removal - thermo and photo.

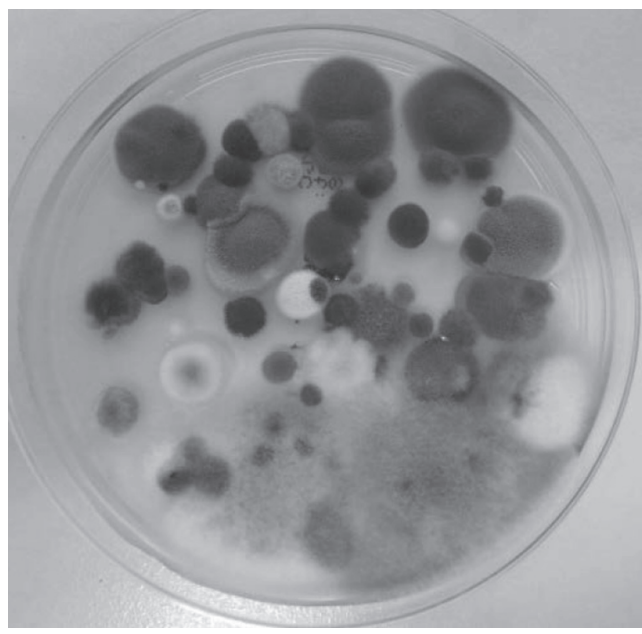

Obr. 13 Kultivace stèru zdi-roh pod podlahou.

Fig. 13 Cultivation of swab of the wall-corner under the floor.

kuchyňské digestoře. Stěny domu jsou beze skvrn a známek růstu plísní. Mikroklimatické podmínky jsou udržovány v optimu, vlhkost zdiva do $1,5 \%$.

Na obr. 11 je prezentován dům prŕípadu č. 3 pohledem severní stranu objektu. Na obr. 12 jsou fotografie kritického místa a jejich termosnímek - na snímku je zobrazeno, jak z dutiny proudí teplý vzduch.

Po odstranění podlahové lišty v problematickém rohu došlo k objevení dutiny v podlahovém systému, která korespondovala $\mathrm{s}$ vnitřním prostorem místnosti. Snímek z termokamery ukazuje proudění teplého vzduchu z dutiny, pravděpodobně leží blízko teplovodního kanálku. Při spuštění digestoře je proudění výrazně zesíleno.

Na obr. 13 je fotografie Petriho misky s kultivací stěru zdi z rohu pod podlahou. Na obr. 14 je fotografie Petriho misky s kultivací po odběru vzduchu aeroskopem.

Závěr: Zdrojem zápachu je skutečně plíseň pocházející $\mathrm{z}$ dutiny pod podlahou. $\mathrm{V}$ dutině velmi pravděpodobně dochází ke kondenzaci vzdušné vlhkosti a růstu plísní. Dutinu bude nutno prozkoumat, sanovat a vyplnit inertním materiálem.

\section{ZÁVĚR}

Z uvedených př́ipadů je patrno, že problémy s napadením plísněmi se nevyhýbají ani novostavbám s moderním technickým

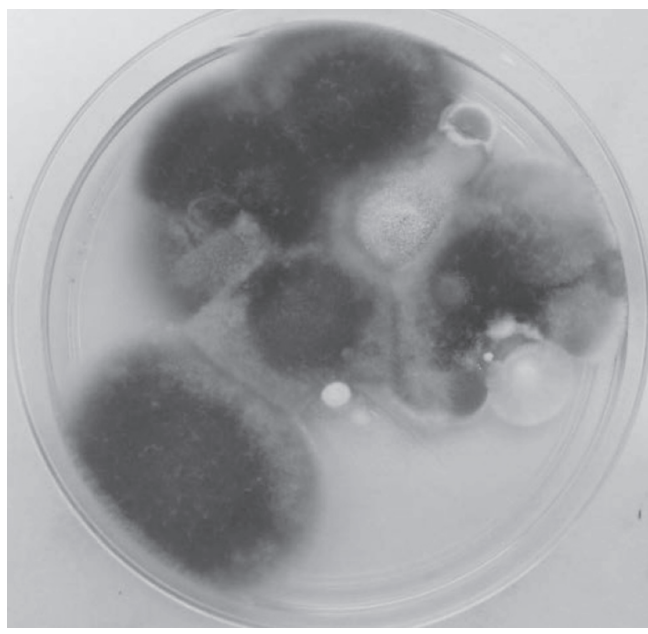

Obr. 14 Kultivace po odběru vzduchu aeroskopem v problematickém rohu $-150 \mathrm{KTJ} / \mathrm{m}^{3}$.

Fig. 14 Cultivation after air sampling by aeroscope in the problematic corner - $150 \mathrm{CFU} / \mathrm{m}^{3}$.

vybavením. Vzhledem k poměrně rychlému šíření spor plísní na vhodná místa objektu nestačí pouhá sanace postiženého místa, ale je třeba rychle nalézt príícinu biologického ataku a problém vyřešit. Posouzení napadení objektu plísněmi a nalezení prríčiny napadení vyžaduje provést celou řadu měření a stanovení - jak na místě, tak v laboratoři. Pro komplexní posouzení problému je ideální spolupráce odborníků z více oblastí.

\section{LITERATURA}

[1] WASSERBAUER, R. Biologické znehodnoceni staveb. 1. vyd. Praha: ABF, Nakladatelství ARCH, 2001, 257 s. ISBN 80-86165-30-2.

[2] KLÁNOVÁ, K. Plisně v domé a bytě: odstrañování a prevence. 1. vyd. Praha: Grada, 2013, 104 s. Profi \& hobby. ISBN 978-80-247-47903.

[3] KUBÁTOVÁ, A. Houby v našich domácnostech aneb o čem doma vite i nevite. Živa. Academia, 2012, 2012(5). ISSN 0044-4812

[4] HANULÁKOVÁ, D. Plísně našich domácností a jejich odstraňování. Alergie a alergeny. 13. setkání lékařŭ ČR a SR. Litomyšl 2014.

[5] KHAN, A. A. H., KARUPPAYIL, S. M. Fungal pollution of indoor environments and its management. Saudi Journal of Biological Sciences. 2012(19), 405-426. 
[6] KLÁNOVÁ, K. Standardni operačni postupy pro vyšetřování mikroorganismů v ovzduši a pro hodnocení mikrobiologického znečištěni ovzduši ve vnitřním prostředí: Praha, listopad 2001. Praha: Státní zdravotní ústav, 2002, 21 s. Acta hygienica, epidemiologica et microbiologica.

[7] ČSN ISO 18593 Mikrobiologie potravin a krmiv. Horizontální metody specifikujici techniky vzorkováni z povrchu pomocí kontaktních ploten a stěrů. Český normalizační institut, září 2006. $11 \mathrm{~s}$.
[8] ČESKO. Vyhláška č. 6/2003 MZČR O fyzikálních, chemických a biologických ukazatelich pro vnitřni prostředi pobytových mistností. In: Sbírka zákonů České republiky. 2003, částka 4, s. 121-125. ISSN 1211-1244.

[9] ČSN ISO 7954 Mikrobiologie. V̌seobecné pokyny pro stanoveni počtu kvasinek a plísní. Technika počitání kolonii vykultivovaných při $25^{\circ} \mathrm{C}$. Český normalizační institut, zárí 1994. $8 \mathrm{~s}$.

\section{Správná citace:}

KUKLETOVÁ, I., BUCHTA, P. Posouzení napadení objektu plísněmi. Soudní inženýrství, 2019, 30(1), 18-24. DOI: http://dx.doi. org./10.13164/SI.2019.1.18. ISSN 1211-443X. 